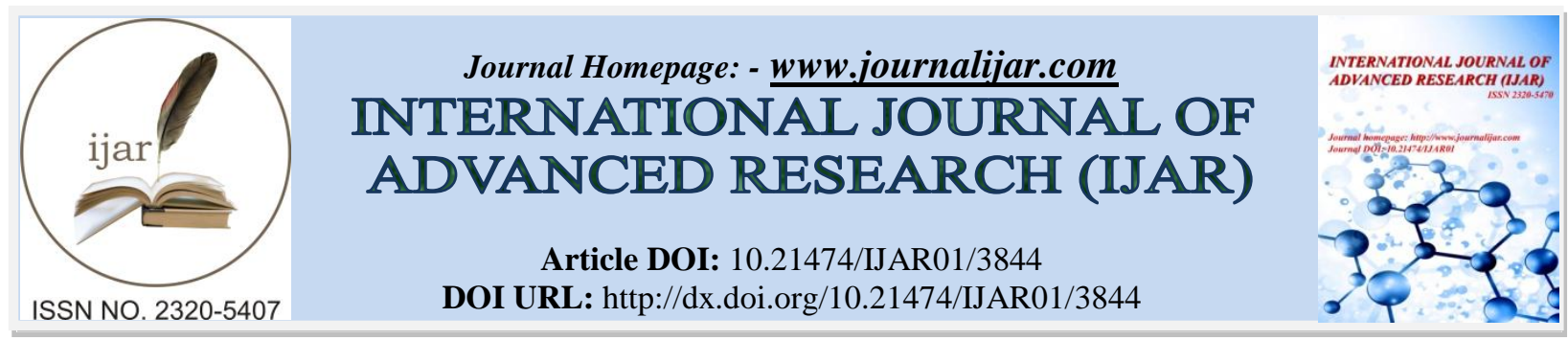

RESEARCH ARTICLE

\title{
AN INVESTIGATION INTO FACTORS AFFECTING SUCCESSFUL COMPLETION OF DEVELOPMENT PROJECTS IN PUNJAB, PAKISTAN.
}

Saif Ur Rehman, CAO Qingren*, Pervaiz Iqbal, Imran Khan and Muhammad Sajid. School of Management, China University of Mining and Technology, Xuzhou (221116), Jiangsu, P.R China ${ }^{1^{\prime 2}{ }^{\prime 4}}{ }^{5}$. University of Quebec in Montreal, Canada ${ }^{3}$

\section{Manuscript Info}

Manuscript History

Received: 02 February 2017

Final Accepted: 01 March 2017

Published: April 2017

Key words:-

Automatic Linear Modeling

Development Projects

Project Management

Punjab, Pakistan.

\begin{abstract}
Development projects are considered essential for progress of a country as they provide necessary infrastructure and initial resources to begin economic activities in various sectors of society and economy. Pakistan suffered from severe scarcity of infrastructure right after its formation in 1947; subsequent government plans and actions in this regard have not been able to deliver desired results. A large number of cities are still lacking basic structure of transportation, healthcare, education and telecommunication that are necessary to drive economic activities. Second to shortage of resources to deliver these facilities there is a big reason of failure in managing these projects to deliver desired quality and value. This paper is an attempt to use proven statistics techniques to analyze project data obtained from relevant research and evaluation reports on previous development projects to provide a model into what are the significant factors that need to be taken care of to ensure better value from these projects.
\end{abstract}

Copy Right, IJAR, 2017,. All rights reserved.

\section{Introduction:-}

Statistic techniques are important to analyze available data for important trends and find significant relations between variables. Statistical modeling techniques offer essential insight into data to derive reliable information for decision making, when applied correctly, these models can produce results of higher accuracy and trust. Focus of this study is to establish a model of various factors that may affect outcomes and value from a development project with the help of statistical modeling techniques. The choice of these methods was made for being useful in subjecting uncertain situations to the rigors of a pre-defined and proven mathematical model. With the help of historical data about what went wrong with the projects of past, these techniques can help embody prior experience to a greater extent and therefore a model thus developed is believed to be less biased than human thought processes alone.

According to Wai et al., 2013 the projects for development of infrastructure are crucial for achieving sustainable development and these developments to be considered sustainable, must ensure that an area's inhabitants have their vital needs met in a way that can be sustained in the future (Naess, 2001). Development projects consist of activities undertaken to create a unique product or service for overall benefit of masses and in less educated and developing societies like Pakistan, these projects are often politically motivated and conceived by an individual without much thought and experience. Very little time is allocated for necessary planning and feasibility analysis resultantly during the execution of these projects, the project manager has to work with higher degree of probability causing 
rise of risk and uncertainty. To mitigate this risk project planners have to allocate more resources which ultimately raise cost and time for completion. This leads to the reason why cost of similar activities are perceived higher in a development project when compared to private sector projects.

Projects being unique and one time activities with presence of uncertainty are managed with attitudes different from other activities and operations. Essential operations of project management are based on probabilities as neither cost nor time could be accurately estimated. Hence, completion times are also based on probabilities. Historically developed models in project management provide time estimates based on optimistic, pessimistic and most likely. These three time scenarios are mathematically assessed to determine the probable completion dates which further impose doubts over all other aspects of project and the final outcome in terms of quality and value.

According to Shieh and Chich-Jen, 2012 having a strategy to learn from the previous mistakes is necessary; a strategy to complement available knowledge from everyday interactions and inculcating it into standard operating procedures makes a basis of improvement by ensuring availability of applicable knowledge for improved performance in future. Better training of management and team is known to have greater impact on project efficiency. Previous studies prove that having advanced knowledge of situations improves chances of success in project management.

It should be noted that such statistical models have been produced in other sectors and have proven successful (Xuan et al., 2015; Zakria et al., 2013), but their implementation on development projects is not giving desired results. One reason of it is the different nature and operations of development projects, and second is the difference in social and political scenario of Pakistan. The purpose of the study is to explore the factors that impacted the success of past development projects in the province of Punjab and then use statistics techniques to provide a model for better planning and execution in future.

This study will focus on all the core areas of development projects as discovered in the preliminary analysis to be responsible for successful completion of a project, right from the initiation of a project till the closing and handing over to the stake holders. Further the flow of all the activities will be considered and assessed for their contribution towards success of a development project, based on current and historical data these results will be presented as a statistical model. This research is likely to produce useful implications, not just for policy formulation and decision making but also to make the development projects more credible and neutral in respect of better management. Contributing to existing literature, this research will form a basis for further research towards increasing productivity and transparency of development projects.

\section{Literature Review:-}

The focus of our research is application of the statistical modeling techniques to measure the success of development projects in Punjab, Pakistan. After the 18th amendment and the $7^{\text {th }}$ National Finance Commission (NFC) awards, provinces are autonomous bodies to set up infrastructure, healthcare and energy projects from their resources as per needs of local public (Jaffery et al., 2013). Punjab government is highly proactive assessing needs of its people and allocating funds for development projects, there are numerous infrastructure, healthcare, energy, transport and information technology projects being run in the province. Planning and development (P\&D) department of Punjab government along-with various departmental project monitoring units (PMUs) are working on these projects. Directorate Monitoring and Evaluation (DG-M\&E) working under P\&D department is responsible for monitoring and evaluation of various phases of projects for successful and in-time completion of development projects initiated by various departments. The Punjab Procurement Regulatory Authority (PPRA) is an important entity of province that ensures rules based and transparent functioning of tendering and procurement process which enhances credibility of development projects.

Approaching to the first quarter of 21 st century, project management has evolved into a more scientific rather than conceptual subject, the concept of iron triangle lately replaced by the value based agile triangle needs to develop further to include more complex metaphors to tackle the challenges of stake holder satisfaction and customer value delivery based on benefits they get from a well managed project. Punjab government has been vigilant in changing itself for creating better value in every aspect of good governance and project management is an exception in no mean, creation of PMUs in departments and equipping them with the best working conditions, human resource and technology has made possible for its projects to complete successfully within time and resources and deliver maximum value to the people of Punjab. 
The base of literature for this research and subsequent statistic model of project success includes a meta analysis report conducted by Directorate General Monitoring and Evaluation (DGM\&E, 2015) which is an assessment of 300 development projects of Punjab government from the year 2011 to 2015. This report highlights pertinent lessons, issues, and findings of evaluation studies for facilitating government departments, researchers and academic institutes to draw practical lessons about project design, implementation and development. From these 300 projects that were evaluated by DGM\&E, only $45(15 \%)$ projects were termed as "good" in performance whereas $201(67 \%)$ displayed "average" and remaining 54 (18\%) termed "poor" in terms of overall value and performance. There is a big concern for government and departments that despite participation at highest level, dedication and determination of staff, still a huge number of projects could not deliver desired results. The report pointed out various factors included in this model that can increase the performance of a development project and make it able to deliver the value intended from it at the time of its inception.

Rockart, 1982 was first to present this idea that by focusing a few areas of project management better results can be obtained. Following the idea many such factor matrixes have been identified in different project categories. Identification and prioritizing these critical success factors can increase the likelihood of achieving success in a project (Garbharran et al. 2012).

A large number of researchers have discussed about success criteria of projects however we can find very little shared ground about it (Al-Tmeemy et al. 2010; Yong and Mustaffa 2012, 2013). One thing that the researchers are frequently found to agree upon is that the success of a project is affected by the performance of each individual activity of the project. An approach often followed by the researchers in numerous studies is focusing on factors that lead to success (Neringa et al., 2014). A number of lists and models have been presented in the literature regarding critical success factors.

\section{Factors contributing to success of development projects:-}

Table no. 1 presents the summary of literature review of various critical success factors. Local project review reports supplemented the literature from international researchers and five distinct areas were identified, consulted and included into the factor matrix as critical for success in local context when applied to development projects of government of Punjab, Pakistan.

\section{Project Related Factors:-}

Project related factors deal with the scope of the project. Five project related factors were identified from the previous literature including (1) Project type, (2) Project nature, (3) Project complexity level, (4) Project size and (5) project location.

\section{Management Related Factors:-}

Choice of management techniques and management information system with a plan to carryout operation is important aspect of success of a project. Preparation of detailed plan and execution of these plans with efficient communication, feedback and control, coordination and monitoring makes the decision making process smooth and effective. Further it makes easier for management to follow schedules and deliver within time, cost and quality to ensure full value of every development project. 
Table No. 1:- Summary of Project Success Factors from Literature.

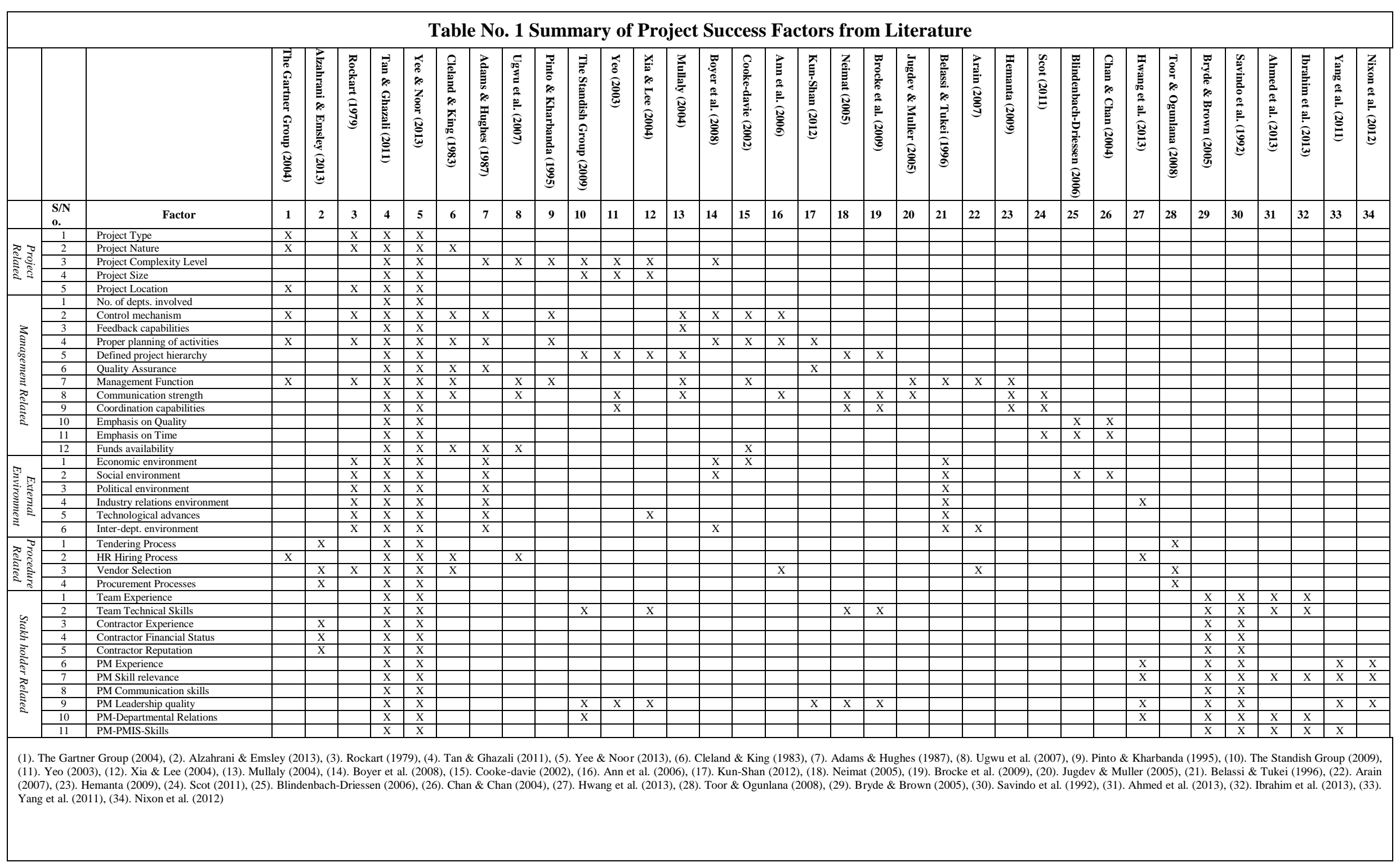


Research work by previous researchers and evaluation reports of different departments about projects being carried out presented twelve management related factors important for successful completion of development projects including (1) Number of departments involved, (2) Control mechanism, (3) Feedback capabilities, (4) Proper activity planning, (5) Defined project hierarchy, (6) Quality assurance, (7) Management function, (8) Communication strength, (9) Coordination capabilities, (10) Emphasis on quality, (11) Emphasis on time and (12) Funds availability.

\section{Procedure Related Factors:-}

The efficiency and integrity of framework of carrying out a project is necessary for its success, procedures like tendering for goods or services and clarity of selection criteria of project contractors and suppliers. Analysis of research work revealed four major procedures responsible for successful completion of development projects including (1) Tendering process, (2) Team Hiring process, (3) Vendor selection and (4) Procurement process

\section{External Environmental Factors:-}

Researchers have recognized environment as a major factor towards success of a project, environment is defined as a set of specific external influencers that impact a project in any way like social, political and technical. The six important external environmental factors found to be critical for successful completion of development projects are (1) Economic environment, (2) Social environment, (3) Political environment, (4) Industry relations environment, (5) Technological advances and (6) Inter-department environment.

\section{Stakeholders Related Factors:-}

As defined by Thomas et al., 2008 the project management, consultants, client, supplier, contractor and subcontractor and all the persons and processes that have tied their success with that of the project are project participants. Researchers have expressed that the dimensions related to the stakeholders of a project like behavior, character, attitude, authority, experience, leadership and motivation of a stake holder are among major determinants of success of a project. From the work of these researchers a total of eleven stakeholders related factors were pointed out namely (1) Team experience (2) Team technical skills, (3) Contractor experience (4) Contractor financial status (5) Contractor reputation (6) Project Manager experience (7) PM skill relevance (8) PM communication skills (9) PM leadership qualities (10) PM departmental relations (11) PM Project Management Information Software skills.

\section{Methodology:-}

Measure: Historic work by researchers and documents of project monitoring and evaluation directorate were used to construct this research framework based on qualitative methodology, responses on specifically designed questionnaire were gathered from perceptions of people who had detailed knowhow about the function of project management and had experienced development projects in their areas. The questionnaire contained 38 dimensions presenting five variables as presented in figure no. 1 above; each dimension was an inquiry about respondent's perception of the role of each factor towards success of a development project. Responses were collected about these statements on lickert's scale from 1, "strongly disagree" to 5, "strongly agree" (Likert-Rensis, 1932)

Data Collection: Primary data 229 responses was collected from three types of respondents firstly government employees working on development projects, secondly the private employees working for contractors assigned to the same development projects and thirdly the project professionals from society who had knowledge about these projects and function of government departments. A demographic analysis and profiles of respondents is as shown in table no. 2 .

Data Validity and Sample Adequacy: Reliability analysis of the instrument used in the model for data collection was performed using SPSS-21 and results are as summarized into table no. 3, all the factor variables were found reliable for this exploratory study with Cronbach's alpha value of 0.71 and above (Black and Porter, 1996).

The adequacy of the sample size was assessed from the value of Kaiser-Meyer-Olkin (KMO) Measure of Sampling Adequacy value of $0.851(\mathrm{p}<0.05)$ as shown in the table no. 4, indicated that the size of current sample was adequate to build a model (Child, 1990). 
Figure No. 1:-

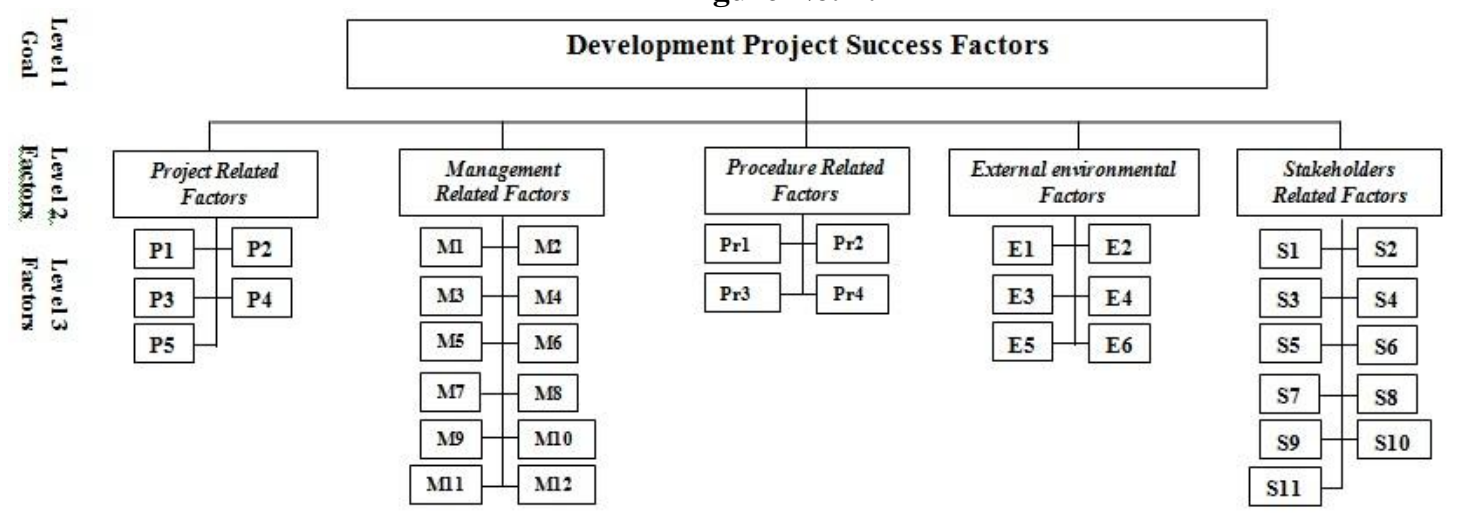

\begin{tabular}{|l|l|l|l|l|}
\hline \multicolumn{5}{|c|}{ Legend for Level 3 Attributes } \\
\hline P1 Project type & M1 Number of departments involved * & Pr1 Tendering process & E1 Economic & S1 Team experience \\
P2 Project nature & M2 Control mechanism* & Pr2 Team Hiring process & environment & S2 Team technical skills \\
P3 Project complexity* & M3 Feedback capabilities* & Pr3 Vendor selection* & E2 Social environment & S3 Contractor experience \\
P4 Project size & M4 Proper activity planning* & Pr4 Procurement process & E3 Political & S4 Contractor financial status \\
P5 project location. & M5 Defined project hierarchy * & & environment * & S5 Contractor reputation \\
& M6 Quality assurance & & E4 Industry relations & S6 Project Manager experience \\
& M7 Management function & & environment & S7 PM skill relevance \\
& M8 Communication strength* & & E5 Technological & S8 PM communication skills \\
& M9 Coordination capabilities & & advances & S9 PM leadership qualities * \\
& M10 Emphasis on quality & & E6 Inter-department & S10 PM departmental relations \\
& M1 Emphasis on time & & environment. & S11 PM Project Management \\
& M12 Funds availability. & & & Information Software skills \\
\hline
\end{tabular}

*Factors perceived insignificant for development projects' success in Punjab.

Factor Reduction: Automatic linear modeling process from SPSS-21 was first run to check the significance and importance of each dimension table no. 5 presents the results of first phase, a total of 28 dimensions from 38 were selected based on significance and importance scores obtained from automatic linear modeling.

Model Building: In second phase of analysis all the five variables were computed based on 28 significant dimensions now automatic linear modeling process was employed using SPSS-21 to construct the project success model. Output of the model is briefly explained and presented in form of easily interpretable graphs as shown in section 5 of this paper from figure no. 2 to figure no. 5 .

Table No. 2:- Respondent Profiles.

\begin{tabular}{|l|l|l|l|}
\hline \multicolumn{2}{|l|}{} \\
\hline Gender of Respondents $(\mathbf{N = 3 2 9 )}$ & No. & Percent & Cumulative Percent \\
\hline Female & & & \\
\hline Male & 82 & 24.9 & 24.9 \\
\hline Profession of Respondents $(\boldsymbol{N}=\mathbf{3 2 9})$ & 247 & 75.1 & 100.0 \\
\hline Government employees working on projects & & & \\
\hline Private employees working on Projects & 120 & 36.5 & 36.5 \\
\hline Professionals having project knowledge and experience & 85 & 25.8 & 62.3 \\
\hline Education of Respondents $(\boldsymbol{N = 3 2 9 )}$ & 124 & 37.7 & 100.0 \\
\hline Masters Degree & & & \\
\hline Bachelors Degree & 44 & 13.4 & 13.4 \\
\hline Technical Skill Certificate & 268 & 81.5 & 94.9 \\
\hline Years of Working Experience $(\mathbf{N = 3 2 9 )}$ & 17 & 5.2 & 100.0 \\
\hline $1 \sim 5$ Years & & & \\
\hline 5 10 Years & 190 & 57.8 & 57.8 \\
\hline 10 20 Years & 92 & 28.0 & 85.7 \\
\hline
\end{tabular}




\begin{tabular}{|l|l|l|l|}
\hline Types of Projects(N=329) & & & \\
\hline Infrastructure Projects (Road, Building, Bridge, Underpass) & 67 & 20.4 & 20.4 \\
\hline Education/Skill/Capacity Development/Healthcare Projects & 49 & 14.9 & 35.3 \\
\hline IT/MIS Projects & 89 & 27.1 & 62.3 \\
\hline Other experience & 124 & 37.7 & 100.0 \\
\hline
\end{tabular}

Table No. 3:- Reliability Analysis of Model Instrument.

\begin{tabular}{|l|c|c|}
\hline Success Factor & Reliability (Cronbach Alpha) & No of Items \\
\hline Project Related Factors & 0.790 & 5 \\
\hline Management Related Factors & 0.906 & 6 \\
\hline Environment Related Factors & 0.711 & 4 \\
\hline Procedure Related Factors & 0.877 & 11 \\
\hline Stakeholders Related Factors & 0.868 & 6 \\
\hline
\end{tabular}

Table No. 4:- KMO and Bartlett's Test.

\begin{tabular}{|l|c|c|}
\hline \multicolumn{2}{|c|}{ Kaiser-Meyer-Olkin Measure of Sampling Adequacy. } & .851 \\
\hline Bartlett's Test of Sphericity & Approx. Chi-Square & 874.988 \\
\cline { 2 - 3 } & df & 10 \\
\hline & Sig. & .000 \\
\hline
\end{tabular}


Table No. 5:- Significant Level 4 Factors, prioritized as per importance score Target: Project_Success

\begin{tabular}{|l|l|l|l|l|l|l|}
\hline Source & Sum of Squares & df & $\begin{array}{l}\text { Mean } \\
\text { Square }\end{array}$ & F & Sig. & Importance \\
\hline Corrected Model & 72.920 & 62 & 1.176 & $11,963.20$ & .000 & \\
\hline Project_type & 0.082 & 3 & 0.027 & 277.548 & .000 & 0.113 \\
\hline Coordination_Capabilities & 0.073 & 3 & 0.024 & 246.955 & .000 & 0.100 \\
\hline PM_experience & 0.062 & 3 & 0.021 & 209.348 & .000 & 0.085 \\
\hline Project_size & 0.060 & 3 & 0.030 & 305.466 & .000 & 0.083 \\
\hline HR_hiring_process & 0.057 & 3 & 0.029 & 290.234 & .000 & 0.078 \\
\hline Funds_availability & 0.046 & 3 & 0.015 & 156.837 & .000 & 0.064 \\
\hline Tendering_process & 0.046 & 3 & 0.015 & 155.785 & .000 & 0.063 \\
\hline Contractor_experience & 0.043 & 2 & 0.022 & 219.477 & .000 & 0.059 \\
\hline PM_communication_skills & 0.035 & 2 & 0.018 & 180.450 & .000 & 0.049 \\
\hline Technological_advances & 0.034 & 2 & 0.017 & 173.281 & .000 & 0.047 \\
\hline Economic_environment & 0.031 & 3 & 0.010 & 105.512 & .000 & 0.043 \\
\hline Contractor_financial_status & 0.023 & 2 & 0.011 & 114.605 & .000 & 0.031 \\
\hline PM_skill_relevance & 0.022 & 2 & 0.011 & 109.819 & .000 & 0.030 \\
\hline Social_environment & 0.014 & 2 & 0.007 & 72.532 & .000 & 0.020 \\
\hline Inter_department_environment & 0.012 & 3 & 0.004 & 39.095 & .000 & 0.016 \\
\hline PM_department_relations & 0.011 & 3 & 0.004 & 38.399 & .000 & 0.016 \\
\hline Management_function & 0.011 & 2 & 0.005 & 55.472 & .000 & 0.015 \\
\hline PM_PMIS_skills & 0.010 & 2 & 0.005 & 53.066 & .000 & 0.014 \\
\hline Team_technical_skills & 0.010 & 2 & 0.005 & 49.366 & .000 & 0.013 \\
\hline Project_nature & 0.007 & 2 & 0.004 & 36.691 & .000 & 0.010 \\
\hline Precurement_processes & 0.006 & 2 & 0.003 & 31.118 & .000 & 0.008 \\
\hline Emphasis_on_quality & 0.006 & 3 & 0.002 & 20.456 & .000 & 0.008 \\
\hline Industry_relations_environment & 0.006 & 2 & 0.003 & 28.991 & .000 & 0.008 \\
\hline Project_location & 0.005 & 1 & 0.005 & 53.659 & .000 & 0.007 \\
\hline Team_experience & 0.005 & 1 & 0.005 & 53.521 & .000 & 0.007 \\
\hline Contractor_reputation & 0.004 & 1 & 0.004 & 40.826 & .000 & 0.006 \\
\hline Emphasis_on_time & 0.004 & 2 & 0.002 & 19.901 & .000 & 0.005 \\
\hline Quality_assurance & 0.002 & 1 & 0.002 & 16.722 & .000 & 0.002 \\
\hline Residual & $\mathbf{0 . 0 2 6}$ & $\mathbf{2 6 6}$ & $\mathbf{0 . 0 0 0}$ & & & \\
\hline Corrected Total & $\mathbf{7 2 . 9 4 7}$ & $\mathbf{3 2 8}$ & & & & \\
\hline & & & & & \\
\hline
\end{tabular}




\section{Automatic Linear Modeling:-}

Automatic linear modeling was used to present results of the model due to the reason that the output is available in form of easily interpretable graphs which can be studied and explained to people without requiring in-depth knowledge of statistics. Output figures, graphs and tables obtained after running the model on SPSS-21 is briefly explained below.

Figure No. 2:-

\section{Model Summary}

\begin{tabular}{|l|l|}
\hline Target & Project_Success \\
\hline Automatic Data Preparation & On \\
\hline Model Selection Method & None (All Predictors Entered) \\
\hline Information Criterion & $-1,414.091$ \\
\hline
\end{tabular}

The information criterion is used to compare to models. Models with smaller information criterion values fit better.

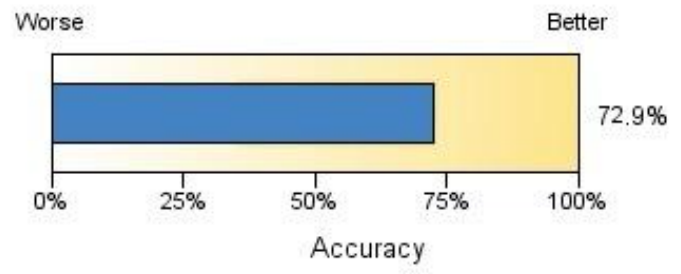

The model summary shown in Figure No.2 presents how the model was constructed using available data, it also provides information about the target variable, data preparation and number of predictors selected from available predictors to build the model, in this case all the available predictor variables were included into the model. The Accuracy bar shown in the graph at the bottom of the figure is the value of adjusted R square as 0.729 which tells how much the predictor variable predicted on dependent variable's functioning, or the percentage of goodness or accuracy of the model, which in this case is $72.9 \%$ and is fairly good enough to declare the model an accurate and fit model. 
Figure No. 3:-

Residuals

Target: Project_Success

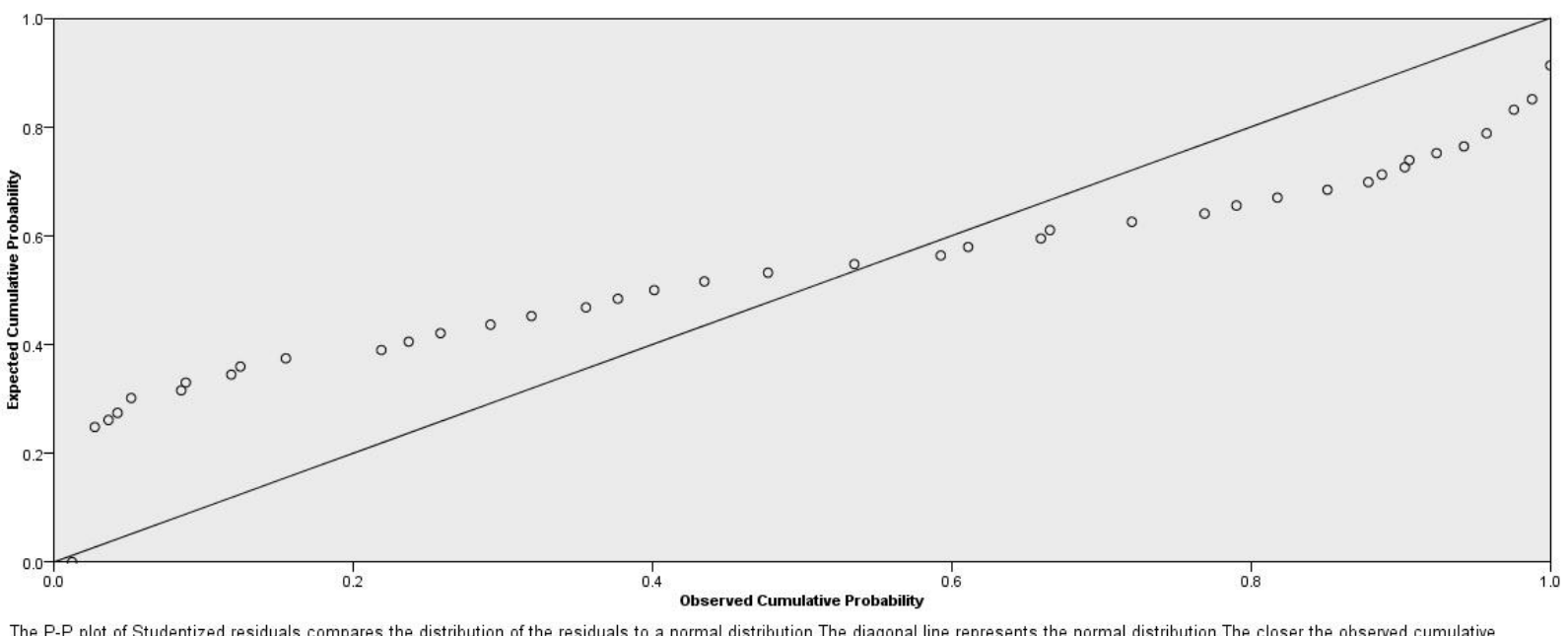

The P-P plot of Studentized residuals compares the distribution of the residuals to a normal distribution. The diagonal line represents the normal distribution. The closer the observed cumulative

Figure No. 3 presents the graphical model of spread of residuals on a probability plot and all the predictions are spread evenly on the line which presents that the most of the time data points are on or close to the line and evenly distributed around the line.

Figure No. 4:Coefficients

Target: Project_Success

\begin{tabular}{|c|c|c|c|c|c|c|c|}
\hline \multirow{2}{*}{ Model Term } & \multirow{2}{*}{ Coefficient $\boldsymbol{\nabla}$} & \multirow{2}{*}{ Std.Error } & \multirow{2}{*}{$\mathbf{t}$} & \multirow{2}{*}{ Sig. } & \multicolumn{2}{|c|}{ 95\% Confidence Interval } & \multirow{2}{*}{ Importance } \\
\hline & & & & & Lower & Upper & \\
\hline Intercept & -0.574 & 0.069 & -8.384 & .000 & -0.709 & -0.440 & \\
\hline $\begin{array}{l}\text { Stakeholders_Related_Factors_ } \\
\text { transformed }\end{array}$ & 0.250 & 0.015 & 16.571 & .000 & 0.220 & 0.280 & 0.294 \\
\hline $\begin{array}{l}\text { Procedure_Related_Factors_ } \\
\text { transformed }\end{array}$ & 0.225 & 0.016 & 14.236 & .000 & 0.194 & 0.256 & 0.217 \\
\hline $\begin{array}{l}\text { Environment_Related_Factors_ } \\
\text { transformed }\end{array}$ & 0.211 & 0.016 & 13.338 & .000 & 0.180 & 0.242 & 0.190 \\
\hline $\begin{array}{l}\text { Project_Related_Factors_ } \\
\text { transformed }\end{array}$ & 0.246 & 0.019 & 12.952 & .000 & 0.209 & 0.283 & 0.180 \\
\hline $\begin{array}{l}\text { Management_Related_Factors_ } \\
\text { transformed }\end{array}$ & 0.200 & 0.019 & 10.551 & .000 & 0.163 & 0.237 & 0.119 \\
\hline Management_Related_Factors_transformed & & & & & Stakehold & Related_Fact & tors_transtormed \\
\hline $\begin{array}{l}\text { Least Important } \\
\text { Display coefficients with sig. values les }\end{array}$ & s than... & 1 & & & 1 & & Most Important \\
\hline $\begin{array}{c}1 \\
.0005\end{array}$ & $\begin{array}{c}1 \\
.005\end{array}$ & $\begin{array}{c}1 \\
.01\end{array}$ & & $\begin{array}{l}7 \\
.05\end{array}$ & $\begin{array}{c}1 \\
.10\end{array}$ & $\begin{array}{c}1 \\
20\end{array}$ & $\begin{array}{c}1 \\
1.00\end{array}$ \\
\hline
\end{tabular}

The coefficients table in figure no. 4 above presents the coefficient values with $t$ statistics and significance of each predictor variable with 95 percent confidence interval. The importance of each predictor gives an idea on how each 
factor is responsible for success of project. The same information is plotted into a graph where length and thickness of lines presents the importance of every independent variable towards dependent or predicted variable. Low value of significance shows that the factors are all significantly recommended to be included into the model as the predictor with low p-value will be a meaningful addition to our project success model because any change in the value of this predictor is related to subsequent change in the response variable of the model which in this case is development project's success.

\section{Discussion on Results:-}

As the model is prepared using only the factors that were found significant during the first phase of analysis, importance scores were the next important figure towards finding contribution of each factor. Factors with importance scores lower than 0.001 were ignored, thus a total of 28 factors were finalized to be included into the model. The higher the importance figure of a factor the higher is the contribution of the factor towards the success of development projects.

Stakeholder related factors round up about 29.4\% $(\mathrm{t}=16.571, p<0.001)$, among the stakeholders related factors the experience of project manager contributed the highest $8.5 \%$ ( $\mathrm{f}=209.348, \mathrm{p}<0.000$ ), followed by contractor experience $5.9 \%(\mathrm{f}=219.477, \mathrm{p}<0.000)$, communication skills of project manager were found to be contributing $4.9 \%(\mathrm{f}=180.45, \mathrm{p}<0.000)$, financial status of the contractor amounted to $3.1 \%(\mathrm{f}=114.605, \mathrm{p}<0.000)$ and relevant skills of a project manager followed with $3 \%(\mathrm{f}=109.819, \mathrm{p}<0.000)$ of contribution towards success. Relations of a project manager with various departments related to the project success contributed to $1.6 \%(\mathrm{f}=38.399, \mathrm{p}<0.000)$ and project manager's skills related to use of project management information systems were accounted to contribute $1.4 \%(\mathrm{f}=53.066, \mathrm{p}<0.000)$. Technical skills and experience of the project team contributed $1.3 \%(\mathrm{f}=49.366$, $\mathrm{p}<0.000)$ and $0.7 \%(\mathrm{f}=53.521, \mathrm{p}<0.000)$ respectively and contractor's reputation was found to contribute $0.6 \%(\mathrm{f}=$ $40.826, \mathrm{p}<0.000)$ towards success of a development project.

Project related factors have been found to contribute $18 \%(\mathrm{t}=14.236, p<0.001)$, where factors like project type contributed 11.3\%(f $=277.548, \mathrm{p}<0.000)$, project size $8.3 \%(\mathrm{f}=305.466, \mathrm{p}<0.000)$, project nature $1 \%(\mathrm{f}=36.691$, $\mathrm{p}<0.000)$ and project location shared its contribution of $0.7 \%(\mathrm{f}=53.659, \mathrm{p}<0.000)$ towards success.

Management related factors $11.9 \%(\mathrm{t}=10.551, p<0.001)$, among these factors the co-ordination capabilities of the management were found to contribute $10 \%(\mathrm{f}=246.955, \mathrm{p}<0.000)$, making funds available in time contributed to $6.4 \%(\mathrm{f}=156.837, \mathrm{p}<0.000)$, overall management of issues contributed to $1.5 \%(\mathrm{f}=55.472, \mathrm{p}<0.000)$, management's emphasis on quality amounted to $0.8 \%(\mathrm{f}=20.456, \mathrm{p}<0.000)$, emphasis on time to $0.5 \%(\mathrm{f}=19.901, \mathrm{p}<0.000)$ and emphasis on quality accounted $0.2 \%(f=16.722, \mathrm{p}<0.000)$ towards success of a development project.

Procedure related factors subsequently score to, $21.7 \%(\mathrm{t}=14.236, \mathrm{p}<0.001)$, among these factors major contributors included the hiring of staff accounted for $7.8 \%(f=290.234, \mathrm{p}<0.000)$, tendering process $6.3 \%(\mathrm{f}=$ $155.785, \mathrm{p}<0.000)$ and procurement process $0.8 \%(\mathrm{f}=31.118, \mathrm{p}<0.000)$ towards success.

External environment related factors contributed $19 \%(\mathrm{t}=13.338, \mathrm{p}<0.001)$, where technological advancement in the field of project contributed to $4.7 \%(\mathrm{f}=173.281, \mathrm{p}<0.00)$, Economic conditions of the market $4.3 \%(\mathrm{f}=$ 105.512, $\mathrm{p}<0.00$ ), Social environment factor shared $2 \%$ ( $f=72.532, p<0.00)$, Interdepartmental environment $1.6 \%$ ( $f$ $=39.095, \mathrm{p}<0.00)$ and Industry relations environment contributed $0.8 \%(\mathrm{f}=28.991, \mathrm{p}<0.00)$ towards success. 
Figure No. 5:-

\section{Coefficients}

Target: Project_Success

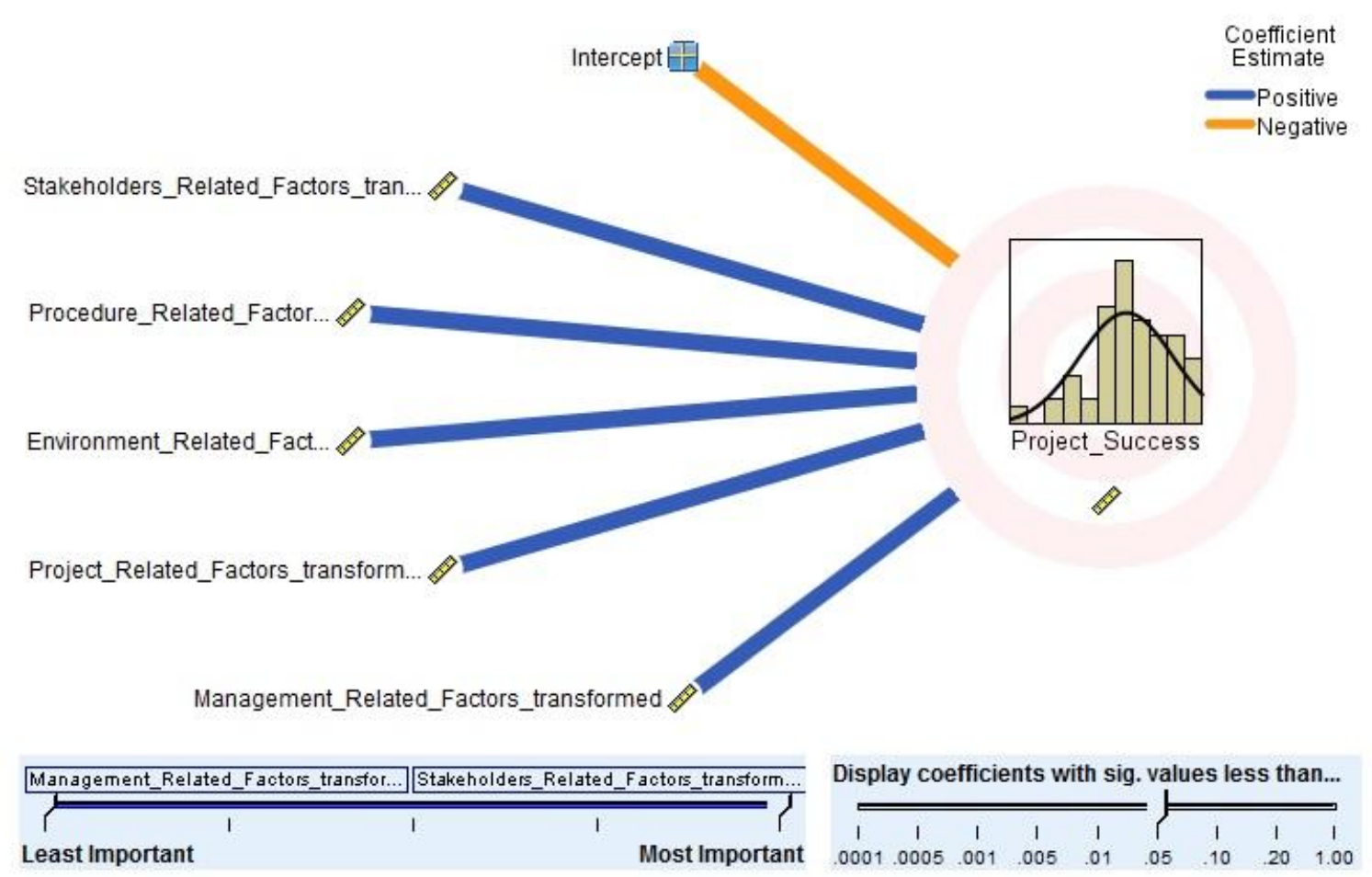

\section{Application and Significance:-}

In addition to providing a functional importance, various success factors depicting percentage of contribution by each significant factor towards success of a project, the model can be a viable tool to point out different factors at planning phase of a project and allocate management resources as per importance scores.

When project priorities will be communicated according to the importance scores, the project manager as well as the project stakeholders like contractors, suppliers and others can join resources to make sure the project goals are aligned with actions at each and every level of project execution. The model also provides an evaluation tool that evaluate and indentifies the management risks if subjective and objective factors identified in this model are not followed due to certain reasons.

Results of this model can be incorporated into various operations of development projects like planning, execution, monitoring and evaluation. The model is also a useful tool for selection of type, nature and location of development projects to get better overall credibility for value to the society, as concentration on a few types of projects like roads and transport can come under criticism, the project selected using such a model will become more credible and are easy to win public support. Similarly, adopting a model for longer time and incorporating lessons can act as a source of feedback on project success which will be beyond the framework of objective metrics alone. The relative scores of importance of various activities in this model can be contributors to the available knowledge base of the departments involved in development projects across the province, this can help to balance priorities and optimal allocation of resources in future development projects.

\section{Limitations and Suggestions for Future Research:-}

The model presented in this article has provided significant evidence and suggested that proper management of identified success factors can enhance the chances of success of a development project and increase its value. In this study, a total of 329 respondents that include the staff of various departments of government of the Punjab who had experience of working on development projects and project management professionals having experience of 
working of provincial government departments. This study can further be expanded to increase the data size and diversity of participants. Further, the model should be used in various projects in different provinces of Pakistan to validate and confirm these results. Additionally, the leadership and adoption of available technology roles could be different based on the disposition of project characteristics and the nature of the project. Likewise, management roles could be project nature specific due to differing types of work cultures and competitive environments. Future research efforts should consider this model for longitudinal research running parallel on projects of different type, scale, nature and complexity in various locations to further refine the model and make is into comprehensive and acceptable measure of project success.

\section{References:-}

1. Adams, W.M. \& Hughes, F.M.R. (1987). Hazards of large scale irrigation in the African Sahel and Sudan zone. In Millington, A.C., Mutiso, S.K. and Binns, J.A. (Eds) African resources, Volume 2: management. Reading: Reading Geographical Papers 97: 17-29

2. Ahmed, R., Azmi, N., Masood, T.; Tahir, M. \& Ahmad, M. S. (2013). What does project leadership really do? International Journal of Scientific \& Engineering Research 4(1): 1-8.

3. Albert P.C., Chan, D. S., \& Ada P. L. Chan (2004). Journal of Construction Engineering and Management, Vol. 130, pp.153-155, February, 2004.

4. Al-Tmeemy, S. M., H. M.; Abdul-Rahman, H. \& Harun, Z. (2010). Future criteria for success of building projects in Malaysia, International Journal of Project Management 29(3): 337- 348. http://dx.doi.org/10.1016/j.ijproman.2010.03.003

5. Alzahrani, J. I. \& Emsley, M. W. (2013). The impact of contractors' attributes on construction project success: a post construction evaluation, International Journal of Project Management 31(2): 313-322. http://dx.doi.org/10.1016/j.ijproman.2012.06.006

6. Ann T.W., Yu, Q. S., Kirsty H., (2006). An Investigation of Critical Success Factors in Construction Project Briefing by Way of Content Analysis. Journal of Construction Engineering and Management ASCE, 132(11):1178-1186.

7. Arain, F. (2007). Critical success factors of project management practices in Pakistan construction industry. Construction Information Quarterly Journal of the Chartered Institute of Building (CIOB), CIQ Paper No. 224, 9(4):179-185.

8. Belassi, W. \& Tukei, O. (1996). A new framework for determining critical success/ failure factors in projects. International Journal of Project Management, 14(3):141-152.

9. Black, S. A., \& Porter, L. J. (1996). "Identification of the Critical Factors of TQM.” Decision Sciences, 27(1), $1-21$.

10. Blindenbach-Driessen, F. (2006). "Innovation Management in Project-based Firms." Unpublished Doctoral dissertation, Erasmus University, Rotterdam.

11. Boyer, D., Creech, H., \& Paas, L. (2008). Critical success factors and performance measures for start-up social and environmental enterprises. International Institute for Sustainable Development, SEED Initiative Research Program.

12. Brocke, H., Uebernickel, F., \& Brenner, W. (2009).Success factors in IT-projects to provide customer value propositions. In 20th Australasian Conference on Information Systems, Australia.

13. Bryde, D. J., \& Brown, D. (2005). The influence of project performance measurement system on the success of a contract for maintaining motorways and trunk roads. Project Management Journal, 35(4), 57-65.

14. Chan, A. P. C., \& Chan, A. P. L. (2004). "Key Performance Indicators for Measuring Construction Success." Benchmarking: An International Journal, 11(2), 203-221.

15. Child, D. (1990). The essentials of factor analysis, 2nd Ed., Cassel Educational Ltd, London.

16. Cleland, D.I., \& King, W.R., Systems Analysis and Project Management, 1983 (McGraw Hill: New York).

17. Cooke-Davies, T. (2002). The real success factors on projects. International Journal of Project Management, 20(3), 185-190.

18. DGM\&E, (2015). Meta Analysis of 300 development projects, retrived at: October, 12, 2015. Retrived From: http://www.dgmepunjab.gov.pk/index.php?option=com_rubberdoc \&view=category $\&$ id=50\&Itemid=210

19. Garbharran, H.; Govender, J. \& Msani, T. (2012). Critical success factors influencing project success in the construction industry, Acta Structilia 19(2): 90-108.

20. Haiyan X, Shuaifeng L., \& Muhammad, A. (2015). "Statistical Inference Of Geographically And Temporally Weighted Regression Model". Vol. 31(3), pp 307-325. 
21. Hemanta D. (2009). Relational partnerships: the importance of communication, trust and confidence and joint risk management in achieving project success. Construction Management and Economics. Volume 27, Issue 11, 2009 pages 1099-1109. DOI:10.1080/01446190903286564

22. Hwang, B.-G., Zhao, X., \& Ng, S. Y. (2013). Identifying the critical factors affecting schedule performance of public housing projects, Habitat International 38: 214-221. http://dx.doi.org/10.1016/j.habitatint.2012.06.008

23. Ibrahim, K. I., Costello, S. B., \& Wilkinson, S. (2013). Key practice indicators of team integration in construction projects: a review, Team Performance Management 19(3-4): 132- 152. http://dx.doi.org/10.1108/TPM-10-2012-0033

24. Jaffery, Nighat B., \& Mahpara S. (2013). "NFC Awards" (PDF). Pakistan Economic and Social Review. Pakistan Economic and Social Review. Retrieved 4 May 2013.

25. Jugdev K., \& Ralf M. (2005) "A Retrospective Look at Our Evolving Understanding of Project Success," Project Management Journal, 36:4 (2005), pp. 19-31.

26. Kun-Shan W., Li-Ren Y., \& I-Chang, C. (2012) Leadership and Six Sigma project success: the role of member cohesiveness and resource management, Production Planning \& Control, 23:9, 707-717, DOI: 10.1080/09537287.2011.586650

27. Likert, R. (1932). "A Technique for the Measurement of Attitudes". Archives of Psychology 140: 1-55.

28. Muhammad Z., Muhammad Y., Faqir M., \& Sajid M. (2013)."Modelling Fertility Patterns of Pakistan during 1984-2007".Pakistan Journal of Statistics. Vol.29 (4), pp 479-486.

29. Mullaly, Mark E., "PM Success in Organizations, Trends, Best Practices and Next Steps," Proceedings of the IPMA 2004 (2004).

30. Naess, P. (2001). "Urban Planning and Sustainable Development.” European Planning Studies, 9(4), 503-524.

31. Neimat, T. A. (2005). Why IT projects fail. White paper collection. Retrieved from http://www.projectperfect.com.au/info_it_projects_fail.php

32. Neringa G., Audrius B., Valentinas P., \& Nerija B. (2014). Identification and evaluation of the critical success factors for construction projects in Lithuania: AHP approach, Journal of Civil Engineering and Management, 20:3,350-359. DOI: 10.3846/13923730.2014.914082 http://dx.doi.org/10.3846/13923730.2014.914082

33. Nixon, P.; Harrington, M. \& Parker, D. (2012). Leadership performance is significant to project success or failure: a critical analysis, International Journal of Productivity and Performance Management 61(2): 204-216. http://dx.doi.org/10.1108/17410401211194699

34. Pinto, J. and Kharbanda, O. (1995). Successful Project Mangers: Lending your team to success. New York: Van Nostrance Reinhold.

35. Rockart, J. (1979). Chief executives define their own data needs. Harvard Business Review, 57(2):13, 81-93.

36. S. H. Wai, Md Yusof Aminah \& Ismail Syuhaida (2013) Social Infrastructure Project Success Criteria - An Exploratory Study, International Journal of Construction Management, 13:3, 95-104, DOI: 10.1080/15623599.2013.10773218

37. Savindo, V., Grobler, F., Parfitt, K., Guvenis, M., \& Coyle, M. (1992). Critical success factors for construction projects. Journal of Construction Engineering and Management, 118(1), 94-111.

38. Scott D., Stanley S. (2011). Project Management: Success Factors. Encyclopedia of Software Engineering. DOI: $10.1081 / \mathrm{E}-\mathrm{ESE}-120044255$

39. Shieh, Chich-jen (2012)."The Effect of Knowledge Management on Organizational Performance - From the Aspects of Learning Organizations". Pakistan Journal of Statistics. Vol. 28(3), pp 395-408.

40. Tan, D. J.-Z., \& Ghazali, F. E. M. (2011). Critical success factors for Malaysian contractors in international construction projects using Analytical Hierarchy Process, International Conference on Engineering, Project, and Production Management EPPM, 20-21 September, 2011, Singapore, 127-138.

41. The Gartner Group. (2004). How to Increase Your IT Project Success Rate. Retrieved on December, 152015. Retrived from https://www.gartner.com/doc/1531025/increase-it-project-success-rate.

42. The Standish report: Does it really describe a software crisis? Communications of the ACM, 49(8), 15-16.

43. Thomas Ng. S., Tang, Z., \& Palaneeswaran, E. (2009). "Factors contributing to the success of equipmentintensive subcontractors in construction." International Journal of Project Management, 10.1016/j.ijproman.2008.09.006, 736-744.

44. Toor, S. R., \& Ogunlana, S. O. (2008). Critical COMs of success in large-scale construction projects: Evident from construction industry. International Journal of Project Management, 26(4), 420-430.

45. Ugwu, O., \& Kumaraswang, M. (2007). Critical success factor for construction ICT projects — some empirical evidence and lessons for emerging economies. IT conference paper, 12:231-249.

46. Xia, B. W., \& Lee, G. (2004). Grasping the complexity of is development projects. Communications of the ACM, 47(5), 68-74. 
47. Yang, L. R.; Huang, C. F., \& Wu, K. S. (2011). The association among project manager's leadership style, teamwork and project success, International Journal of Project Management 29(3): 258-267. http://dx.doi.org/10.1016/j.ijproman.2010.03.006

48. Yee, C. Y. \& Nur E. M. (2013). Critical success factors for Malaysian construction projects: an empirical assessment. Construction Management and Economics Volume 31, Issue 9, 2013 pages 959-978. DOI:10.1080/01446193.2013.828843

49. Yeo, K. (2003). Critical failure factors in information system projects. International Journal of Project Management, 20(3), 241-246.

50. Yong, Y. C. \& Mustaffa, N. E. (2012). Analysis of factors critical to construction project success in Malaysia, Engineering, Construction and Architectural Management 19(5): 543- 556. http://dx.doi.org/10.1108/09699981211259612 